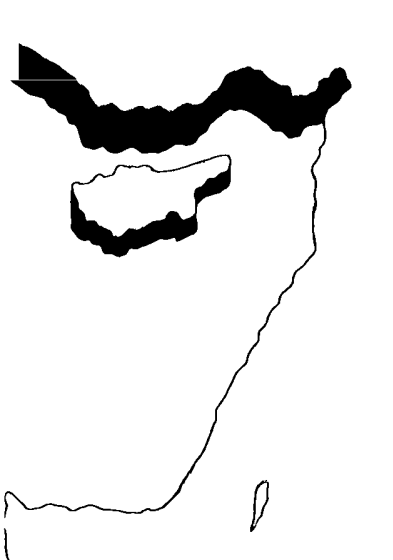

\title{
GEOLOGY OF THE
}

ARABIAN PENINSULA

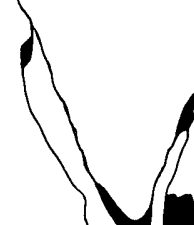

(

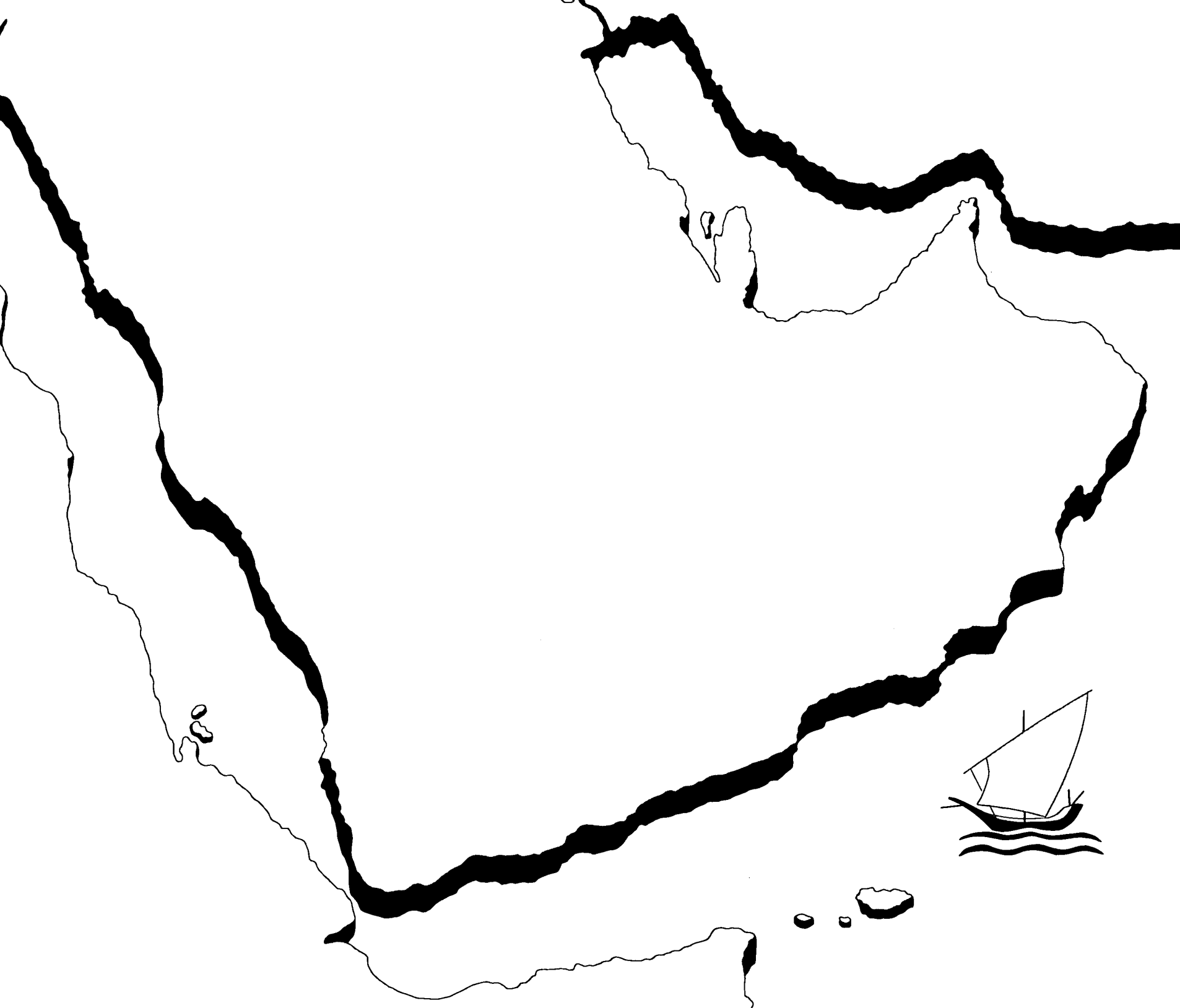

GEOLOGICAL SURVEY PROFESIONAL PAPER 560-E 


\section{Geology of the Arabian Peninsula Bahrain}

By R. P. WILLIS

GEOLOGICAL SURVEY PROFESSIONAL PAPER 560-E

$A$ review of the geology of Bahrain as shown on USGS Miscellaneous Geologic Investigations Map I-270 A, "Geologic Map of the Arabian Peninsula," 1963

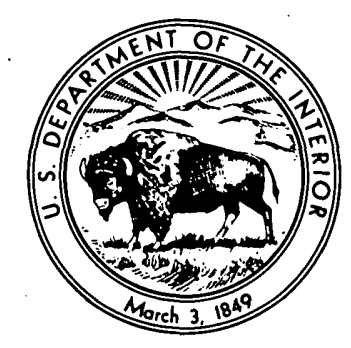

UNITED STATES GOVERNMENT PRINTING OFFICE, WASHINGTON : 1967 
UNITED STATES DEPARTMENT OF THE INTERIOR

STEWART L. UDALL, Secretary

\section{GEOLOGIGAL SURVEY}

William T. Pecora, Director

For sale by the Superintendent of Documents, U.S. Government Printing Office Washington, D.C. 20402 - Price 15 cents (paper cover) 


\section{FOREWORD}

This volume, "The Geology of the Arabian Peninsula," is a logical consequence of the geographic and geologic mapping project of the Arabian Peninsula, a cooperative venture between the Kingdom of Saudi Arabia and the Government of the United States. The ArabianAmerican Oil Co. and the U.S. Geological Survey did the fieldwork within the Kingdom of Saudi Arabia, and, with the approval of the governments of neighboring countries, a number of other oil companies contributed additional mapping to complete the coverage of the whole of the Arabian Peninsula. So far as we are aware, this is a unique experiment in geological cooperation among several governments, petroleum companies, and individuals.

The plan for a cooperative mapping project was originally conceived in July 1953 by the late William E. Wrather, then Director of the U.S. Geological Survey, the late James Terry Duce, then Vice President of Aramco, and the late E. L. deGolyer. George Wadsworth, then U.S. Ambassador to Saudi Arabia, and Sheikh Abdullah Sulaiman, then Minister of Finance of the Government of Saudi Arabia, lent their support to the plan. In November of the following year, 1954, Director Wrather approved the U.S. Geological Survey's participation and designated G. F. Brown responsible for the western Arabian shield region in which he had previously worked under U.S. foreign-aid programs. In January 1955 F. A. Davies, Chairman, Board of Directors, Arabian-American Oil Co., approved Aramco's participation and appointed the late R. A. Bramkamp, chief geologist, responsible for compilation of the area within the Kingdom where the sediments crop out. This responsibility fell to L. F. Ramirez following the death of R. A. Bramkamp in September 1958.

R. A. Bramkamp and G. F. Brown met in New York in February 1955 and planned the program, including scales of maps, areas of responsibility, types of terrain representation, and bilingual names. Thus there was established a cooperative agreement between the Kingdom of Saudi Arabia, the U.S. Department of State, and the Arabian-American Oil Co. to make available the basic areal geology as mapped by Aramco and the U.S. Geological Survey.

The agreement specified publication of a series of 21 maps on a scale of $1: 500,000$, each map covering an area $3^{\circ}$ of longitude and $4^{\circ}$ of latitude. Separate geologic and geographic versions were to be printed for each of the quadrangles; both versions were to be bilingual-in Arabic and English. A peninsular geologic map on a scale of 1:2,000,000 was to conclude the project.

High-altitude photography, on a scale of 1:60,000, of the Kingdom of Saudi Arabia was initiated during 1949 by the Aero Service Corp. and completed in 1959. Both third-order vertical and horizontal control and shoran were utilized in compiling the photography. This controlled photography resulted in highly accurate geographic maps at the publication scale which then served as a base for the geologic overlay. The topography of the sedimentary areas was depicted by hachuring and that of the shield region by shaded relief utilizing the airbrush technique.

The first geographic quadrangle was published in July 1956 and the last in September 1962. While preparation of the geographic sheets was in progress, a need arose for early publication of a $1: 2,000,000$-scale peninsular geographic map. Consequently, a preliminary edition was compiled and published in both English and Arabic in 1958. The second edition, containing additional photography and considerable new topographic and cultural data, was published in 1963. The first of the geologic map series was published in July 1956 and the final sheet in early 1964. The cooperative map project was completed in October 1963 with the publication of the 1:2,000,000-scale "Geologic Map of the Arabian Peninsula" (Miscellaneous Geologic Investigations Map I-270 A). 
As work on the quadrangles progressed, geologists, companies, and governments working in areas adjacent to the Kingdom of Saudi Arabia were consulted by Aramco and invited to participate in the mapping project. The number of cooperating participants was expanded to 11 , which included the operating oil companies in the peninsula and which are identified elsewhere in this text; the Overseas Geological Surveys, London; the Government of Jordan; F. Geukens, who had worked in Yemen; and Z. R. Beydoun, who had studied the Eastern Aden Protectorate. With the close cooperation of the authors, the new data were added to data already plotted on the base map of the Arabian Peninsula.

As the geological coverage of the peninsular map grew, the need for a text to accompany the map became apparent to both the U.S. Geological Survey and the Aramco geologists. Exploratory conversations were begun by Aramco with companies working in the other countries of the Arabian Peninsula for their participation in the preparation of a monograph on the geology of the Arabian Peninsula. Each author prepared a description of the geology of the area for which he was responsible, as shown in the sources of geologic compilation diagram on the peninsular map. The U.S. Geological Survey undertook the publishing of the volume as a professional paper, and the Government of Saudi Arabia was to finance its printing. It was early agreed that there would be no effort to confine the contributions to a standard format and that no attempt would be made to work out an overall correlation chart other than shown on the "Geologic Map of the Arabian Peninsula." Thus, the individual style of authors of several nationalities is preserved.

Cooperation and relations have been of the highest order in all phases of the work. The project would not have been possible without the full support of the U.S. Department of State, the Kingdom of Saudi Arabia, and all contributors. In fact, the funds which made publication of this volume possible were contributed by the Saudi Arabian Government.

The data provided by the maps and in the professional paper provide information for an orderly scientific and economic development of a subcontinent.

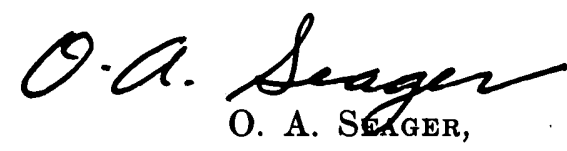
Arabian-American Oil Co. (Retired).

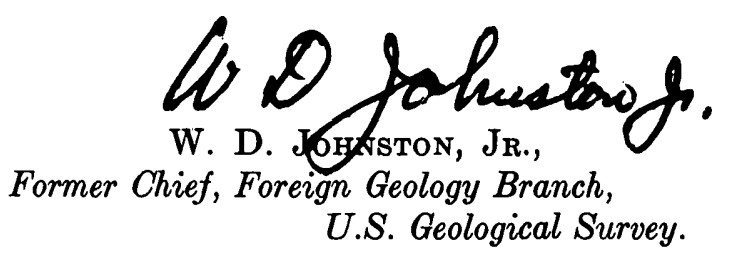




\section{CONTENTS}

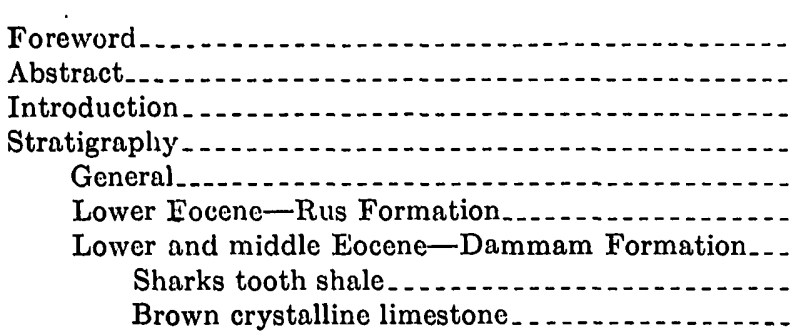

\begin{tabular}{|c|c|c|c|}
\hline Page & & & \\
\hline III & Stratigraphy-Continued & & \\
\hline E1 & Lower and middle & Eocene-Dammam & Forma- \\
\hline 1 & tion-Continued & & \\
\hline 1 & Orange marl & $\ldots$ & - \\
\hline 1 & White limestone. & 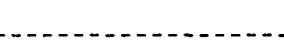 & \\
\hline 3 & Miocene & 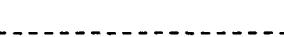 & \\
\hline 3 & Recent & $\ldots$ & \\
\hline 3 & 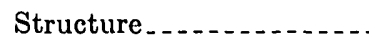 & 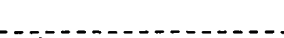 & \\
\hline
\end{tabular}

\section{ILLUSTRATION}

Frgure 1. Geologic map of Bahrain $\ldots \begin{array}{r}\text { Page } \\ \text { E2 }\end{array}$ 


\section{GEOLOGY OF THE ARABIAN PENINSULA}

\section{BAHRAIN}

Bx R. P. Wiluis ${ }^{1}$

\section{ABSTRACT}

The Sheikhdom of Bahrain is a group of islands in the Persian Gulf between the Qatar Peninsula and Saudi Arabia. The discovery well was completed as a producer from the middle Cretaceous in June 1932. The principal outcropping rocks on Bahrain, the main island, are of Eocene age, with Miocene and younger rocks on the periphery. The anticlinal structure is clearly discernible in the rimrock that encircles the central part of Bahrain Island.

\section{INTRODUCTION}

The Sheikhdom of Bahrain (fig. 1) consists of a group of low-lying islands between the Qatar Peninsula and Saudi Arabia at approximately lat $26^{\circ} \mathrm{N}$., long $50^{\circ} 30^{\prime} \mathrm{E}$. The main island of Bahrain is about 48.3 kilometers (30 miles) long and 16.1 kilometers (10 miles) wide and reaches a maximum altitude of 134.1 meters (440 ft) at Jabal ad Dukhān near its geographical center.

The principal subsidiary islands are: Al Muharraq and Sitrah to the northeast, Umm Na'sān to the west, and Huwār to the southeast near the Qatar coast. Numerous other small islands are within the Bahrain territorial boundary.

The geology of Bahrain was first mentioned in 1908 in a memoir by Guy S. Pilgrim, Indian Geological Survey, on the geology of the Persian Gulf region. This study was followed in 1928 by private work by R. O. Rhoades of the Gulf Oil Corp. The discovery well was drilled in 1931-32 by the Standard Oil Co. of California and was completed as a producer from the middle Cretaceous in June 1932. The present rate of oil production is 45,000 barrels per day from 165 wells.

Acknowledgments are made to the Bahrain Petroleum Co., Ltd., and American Overseas Petroleum Ltd., for permission to publish this discussion, and to those who, in the past, contributed numerous reports to the company files on the geology of Bahrain. These reports

\footnotetext{
1 Of the Bahrain Petroleum Co., Ltd.
}

were drawn on extensively during the preparation of this report.

\section{STRATIGRAPHY}

\section{GENERAI}

The principal outcropping rocks on Bahrain Island ${ }^{2}$ are of early and middle Eocene age, with Miocene and younger rocks evident along the periphery. Recent deposits are concentrated in the southern and southwestern parts of the island in the Ra's al Barr and Ra's al Jazā'ir areas.

Eocene and Miocene rocks are also exposed in the Huwār Islands to the southeast, but the other small islands of the Bahrain Group are limited to Pleistocene(?) and Recent deposits, with the exception of Umm Na'sān, which appears to have some Miocene deposits. The dominant rock types within the Eocene and Miocene of Bahrain are limestone, dolomitic limestone, and chalk, with subsidiary marls and shales.

Evidence of wind sculpturing can be seen throughout the islands; erosional remnants and striations have a predominant north-northwesterly orientation. A prominent topographic feature of Bahrain is the rimrock of Eocene limestone which forms a complete ring around the central part of the island. This rimrock in some places supports a cliff face in excess of $30.5 \mathrm{~m}(100 \mathrm{ft})$. The only water gap is on the west.

An angular unconformity is indicated between middle Eocene and younger rocks by variations in thickness of the uppermost Eocene unit and by a change in lithology of the Miocene rocks to a more sandy appearance. The major basin of deposition during Eocene time appears to have been north-northwest of Bahrain in the Al Burqain-As Saffānīyah area, but the Miocene trough was farther to the east.

2 Since publication of the "Geologic Map of the Arablan Peninsula," I-270 A, by the U.S. Geological Survey and Arablan American Oll Co. in 1963, new fieldwork has been completed. Resulting revisions are shown in figure 1. 


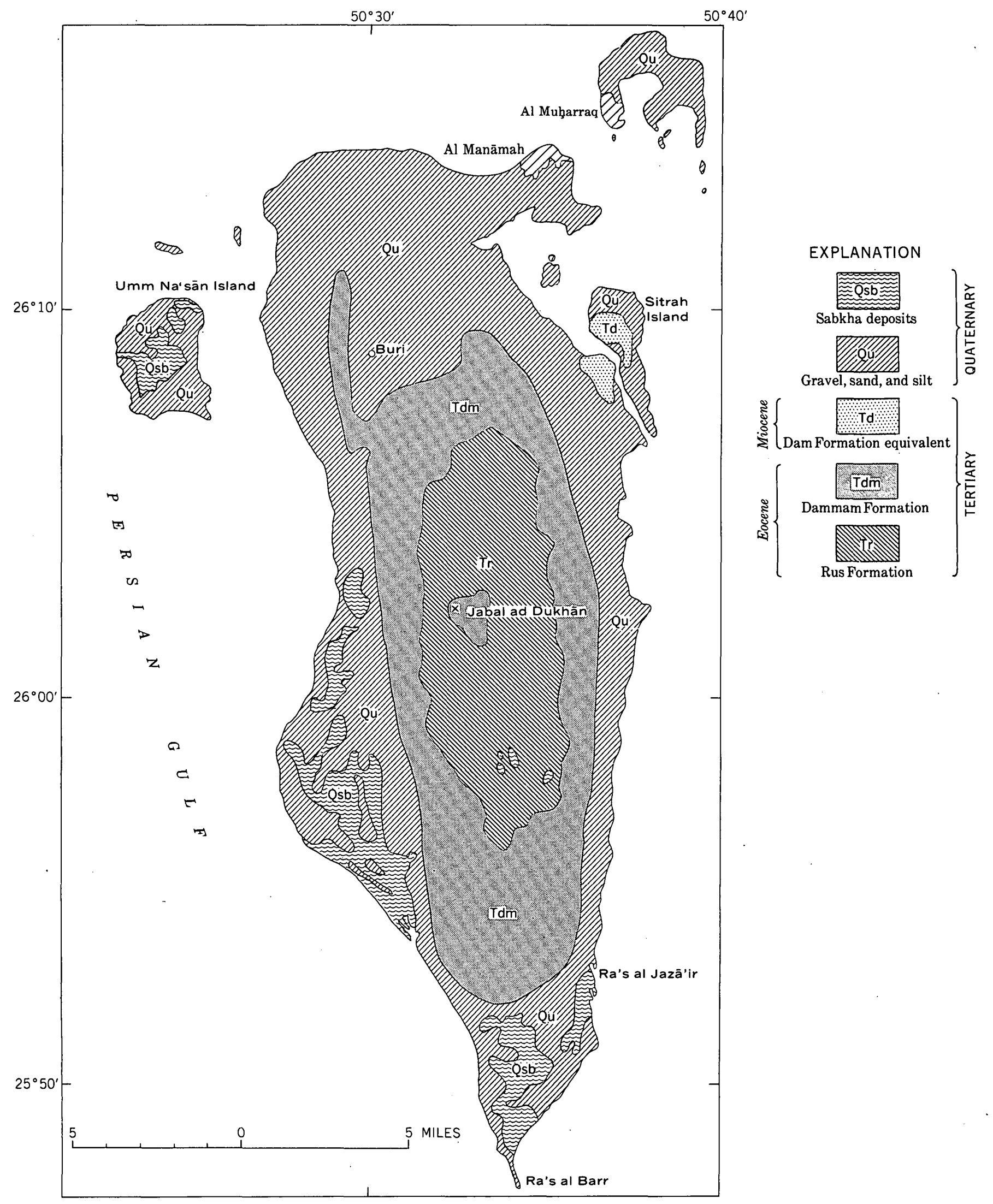

Figure 1.-Geologic map of Bahrain. 
The Bahrain area is near the eastern edge of the Arabian Shelf, which was fairly stable. The prevalent environment of deposition was shallow water that was normal marine to restricted marine. Sedimentation was typical of a shelf area, and individual units extended for great distances laterally.

\section{LOWER EOCENE-RUS FORMATION}

The type section of the Rus Formation is in the Ad Dammān area of Saudi Arabia, and it is approximately $56.1 \mathrm{~m}(184 \mathrm{ft})$ thick. This is the oldest formation outcropping on Bahrain, and it occurs only in the central part of Bahrain Island within the rimrock area, where it reaches a total thickness (surface and subsurface) of about $67.1 \mathrm{~m}(220 \mathrm{ft})$.

The exposed part of this formation consists principally of chalk- and chert-bearing dolomitic limestones. Numerous quartz geodes can be found in many localities and a few have been known to contain petroleum. The only other surface indication of the presence of hydrocarbons is an inactive oil seep in the south-central part of the island on a possible fault trend.

Some anhydritic beds have been observed in the Rus Formation; erratic dips plus the existence of closed topographically low areas and lost circulation in all drilling operations suggest that much of the erosion within the rimrock area has been magnified by slumping of the strata above anhydritic beds that are probably leached.

The base of the Rus Formation is not exposed on Bahrain, but information derived from drilling indicates that the contact with the underlying Umm er Radhuma Formation is conformable.

Little or no paleontologic work has been done on the Eocene and younger rocks of Bahrain, but similar stratigraphic position and lithology have made possible a close correlation with Saudi Arabia to the west.

The Rus Formation on Bahrain is termed the "Zone C aquifer" and is the source of a limited supply of fresh water, the product of local rains, that floats on top of the usually saline water of the formation. The thickness of this fresh-water "cap" may reach 3-4.6 m (10-15 $\mathrm{ft}$ ) in some localities.

The limestones of the Rus are used extensively in the production of lime for the local construction industry.

\section{LOWER AND MIDDLE EOCENE-DAMMAM FORMATION} SHARKS TOOTH SHALE

The basal sharks tooth shale member of the Dammam Formation immediately overlies the "chalky beds" of the Rus Formation and averages between 9.1 and $15.2 \mathrm{~m}$ (30-50 ft) in thickness. It consists of gray to yellow shale and marl and subsidiary thin dolomitized lime- stones. The name given to this interval is derived from the lowest clay-shale bed, in which fossil shark teeth have been found. The upper part of the member is sometimes referred to as the Alveolina zone.

The sharks tooth shale member is believed to correlate with the Midra Shale of Saudi Arabia.

\section{BROWN CRYSTALLINE LIMESTONE}

The brown crystalline limestone member of the Dammam Formation averages $33.5 \mathrm{~m}(110 \mathrm{ft})$ in thickness. Tho rock is brown to buff massive hard porous finely crystalline dolomitic limestone. The lower part contains bands of nodular chert which may be largely responsible for the development of the rimrock that surrounds the central basin of the island. The upper contact with the overlying orange marl is sharp and conformable.

The brown crystalline limestone member of Bahrain is correlated with the Khobar Member of Saudi Arabia, and is the main fresh-water aquifer of Bahrain; it carries the designation of "Zone B aquifer." Salinity increases and static head decreases to the southeast.

\section{ORANGE MARL}

The orange marl unit serves as an impermeable barrier between the overlying Zone $\mathrm{A}$ and underlying Zone $B$ aquifers, and is easily recognized in drilling operations by its distinctive color and its rather sharp contacts with contiguous members. The thickness ranges from 6.1 to $19.8 \mathrm{~m}(20-65 \mathrm{ft})$, the average being approximately $12.2 \mathrm{~m}$ (40 ft).

The rock consists of limonite-stained yellow-orange and brown slightly dolomitic marl; some thin marly limestone is interbedded in the upper part. The equivalent unit in Saudi Arabia is the Alat Marl.

\section{WHITE ITMESTONE}

The white limestone, designated the "Zone A aquifer," ranges from 6.1 to $62.5 \mathrm{~m}(20-205 \mathrm{ft})$ in thickness. Pronounced thickening is noted downdip beneath the Eocene-Miocene unconformity.

This upper member of the Dammam Formation is composed of white very porous finely crystalline commonly chalky and in part dolomitized limestone, and is correlated with the Alat Limestone on the Arabian Peninsula.

Local silicification of the limestone at the surface has resulted in a resistant layer in the form of a prominent scarp in the Būrì area of Bahrain Island and prominent cliffs along the shore of Huwār Island.

The white limestone is a major source of fresh water on Bahrain; however, as is true of the Zone B aquifer, the static head decreases to the southeast and the salinity increases, so that in the southern half of the island, 
practically no fresh water is available from these aquifers.

\section{MIOCENE}

No formal names have been given to the Miocene and younger rocks on Bahrain. The Miocene comprises a sequence of clay, marl, shale, and sandy limestone and

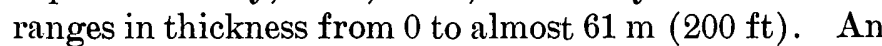
abrupt increase in thickness is noted down flank on the Bahrain anticline.

The basal unit of the Miocene is generally a thin sandy limestone and is considered as part of the Zone A aquifer, whose main component is the underlying white limestone of Eocene age. The thin sandy limestone is overlain by approximately $21.3 \mathrm{~m}(70 \mathrm{ft})$ of soft gray clay and shale, which in turn is overlain by light-colored soft porous sandy limestone and marl. Miocene outcrops of cream to brown limestone and marl have been recognized on Umm Na'sān.

Crossbedded calcareous sandstone composed of masses of Milliolidae occurs at several localities on Bahrain and adjacent islands; it has been considered by some workers to be Miocene and by others to be as young as Pleistocene!' On Hुuwār Island a calcareous sandstone overlying known Eocene strata has been described. On Umm Na'sān Island a similar sandstone is seen to rest unconformably on the Miocene beds, and on Bahrain such sandstone occurs in gaps in the rimrock, resting unconformably on the Eocene strata. These sandstones are believed to be old dune deposits.

The Miocene of Bahrain is believed to be the equivalent of the Dam and Hadrukh Formations of Saudi Arabia and the Lower Fars of Iran.

\section{RECENT}

Recent beach sands are found on all islands of Bahrain, but the most noteworthy deposits occur on Bahrain Island in the Ra's al Jazā'ir and Ra's al Barr areas. In these areas extensive salt flats and marshes (Sabkha deposits) make any surface operations extremely difficult. Beachsand deposits have not been mapped in detail and, as a result, it has not been possible in figure 1 to differentiate them from other unconsolidated sur- ficial deposits of gravel, sand, and silt that cover extensive parts of the islands.

There is also much evidence of Recent limestone and calcareous-mud deposition in the shallow near-shore water of Bahrain; much of this limestone is used in local construction work.

\section{STRUCTURE}

Bahrain is on the Interior Platform (Hasa Structural Terrace), which is a prominent feature of the Arabian Peninsula; the formation of individual structures appears to have resulted from vertical uplift rather than compressive stresses. The only evidence that compressive stresses were active at all is the somewhat steeper west flank of the Bahrain anticline.

The Bahrain anticlinal axis is oriented in a northsouth direction and the structure is fairly simple-no faults visible at the surface. Most faults observed in the subsurface have displacements of less than $15.2 \mathrm{~m}$ $(50 \mathrm{ft})$, and all are classified as normal tension faults.

Early Eocene time was characterized by a shallowwater restricted marine environment as indicated by the presence of anhydrite in the Rus Formation. Increased subsidence during middle Eocene time brought more normal marine conditions, and limestone and shale were deposited. Local and regional uplift near the close of middle Eocene initiated a period of erosion in the Bahrain area, and no upper Eocene or Oligocene sediments have been recognized. Continued local uplift exceeded the regional tilting, and Miocene sediments were deposited in the relatively low areas around the main anticline, unconformably onlapping the Eocene deposits. Further local uplift in the late Miocene and Pliocene caused erosion of some of the Miocene sediments and gave the islands their present configuration. Recent beach-sand accumulations added the flat saltmarsh areas in the south and southwest parts of the main island. The post-Eocene uplift made possible the leaching of anhydrite from the Rus Formation, and the leaching caused slumping along the structural axis. This slumping, together with the prevailing northerly winds, completed the geologic sculpturing of Bahrain. 